ppi $201502 Z U 4645$

Esta publicación científica en formato digital es continuidad de la revista impresa ISSN-Versión Impresa 0798-1406 / ISSN-Versión on line 2542-3185Depósito legal pp $197402 Z$ U34

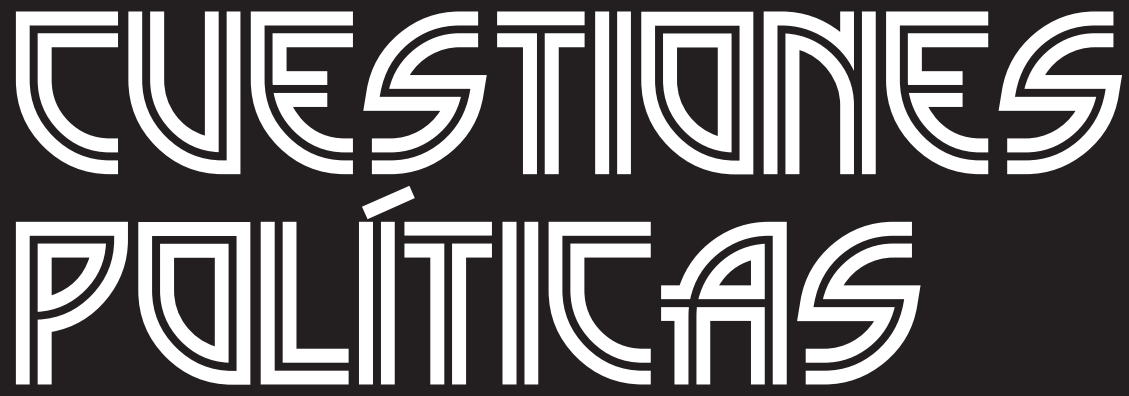

Instituto de Estudios Políticos y Derecho Público "Dr. Humberto J. La Roche" de la Facultad de Ciencias Jurídicas y Políticas de la Universidad del Zulia Maracaibo, Venezuela
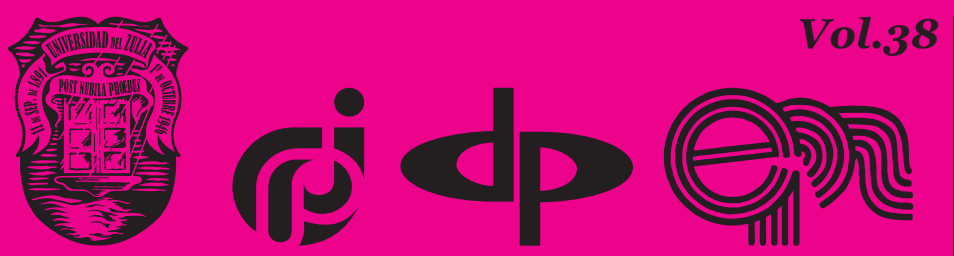

$N^{\circ}$ Especial 1era Parte 2020 


\title{
Features of civil liability of police officers for damage caused under the influence of force majeure
}

\author{
DOI: https://doi.org/10.46398/cuestpol.38e.24
}

\author{
Strelbytska Lilia * \\ Strelbytskyi Mykola ** \\ Shemchuk Viktor *** \\ Rizak Mykhailo **** \\ Kulhavets Khrystyna *****
}

\section{Abstract}

The aim of the article is to analyze the characteristics of civil liability of Ukrainian police officers for damage caused under the influence of force majeure. At a methodological level to achieve the objectives of the article, the following scientific methods were combined: general (dialectical, formal-logical, system-structural) and special (historical, comparative-legal, etc.). Essentially, the concept of force majeure and its characteristics are studied, as well as two main theories of force majeure (objective and subjective). In addition, the main differences between force majeure and case are established. The types of force majeure circumstances and their particular properties are studied. By way of conclusion, the fact that police officers are exonerated from civil liability for causing damage under the influence of force majeure is discussed, if they can prove the effect of this influence. For the rest, given that Ukraine's jurisprudence on the exemption from civil liability of police officers due to force majeure is quite limited to formulating a precedent, it is based on the general rule that, in tort, the recognition that the damage was the result of accidental circumstances excludes the occurrence of liability for damages.

* Doctor of Law, Professor, Head of the Department of Civil Law Disciplines of the National Academy of Security Service of Ukraine, Ukraine. ORCID ID: https://orcid.org/o0oo-0003-0609-2201. Email: academy@ssu.gov.ua

** Doctor of Law, Professor, Principal Reseacher of the National Academy of Security Service of Ukraine, Ukraine. ORCID ID: https://orcid.org/oooo-0oo2-1700-3764. Email: academy@ssu.gov.ua

*** PhD in Law, Honoured Lawyer of Ukraine, Associate Professor of the Department of Constitutional and International Law of V.I. Vernadsky Taurida National University, Ukraine. ORCID ID: https://orcid. org/oooo-ooo3-4938-1919. Email: info@tn.unviersity

**** Doctor of Law, Leading Researcher of the Scientific Institute of Public Law, Ukraine. ORCID ID: https://orcid.org/oooo-0oo1-9622-9114. Email: post@naiau.kiev.ua

*****PhD in Law, Senior Lecturer at the Law Department of the Veterinary Hygiene, Ecology and Law Faculty Stepan Gzhytskyi National University of Veterinary Medicine and Biotechnologies of Lviv, Ukraine. ORCID ID: https://orcid.org/oooo-0003-1900-1954. Email: post@naiau.kiev.ua 
Strelbytska Lilia, Strelbytskyi Mykola, Shemchuk Viktor, Rizak Mykhailo y Kulhavets Khrystyna 372

Features of civil liability of police officers for damage caused under the influence of force majeure

Keywords: force majeure; context of the case; police forces; civil liability; dismissal.

\section{Características de la responsabilidad civil de los agentes de policía por daños causados bajo la influencia de fuerza mayor}

\section{Resumen}

El objetivo del artículo es analizar las características de la responsabilidad civil de los agentes de policía de Ucrania por los daños causados bajo la influencia de fuerza mayor. A nivel metodológico para alcanzar los objetivos del artículo se combinaron los siguientes métodos científicos: generales (dialéctico, formal-lógico, sistema-estructural) y especiales (histórico, comparativo-legal, etc.). Esencialmente se estudia el concepto de fuerza mayor y sus características, así como dos teorías principales de fuerza mayor (objetiva y subjetiva). Además, se establecen las principales diferencias entre fuerza mayor y caso. Se estudian los tipos de circunstancias de fuerza mayor y sus propiedades particulares. A modo de conclusión, se discute el hecho de que los agentes de policía quedan exonerados de responsabilidad civil por causar daños bajo la influencia de fuerza mayor, si pueden probar el efecto de esta influencia. Por lo demás, dado que la jurisprudencia de Ucrania sobre la exoneración de la responsabilidad civil de los agentes de policía por fuerza mayor se limita bastante a formular un precedente, se parte de la regla general de que, en el agravio, el reconocimiento de que el daño fue el resultado de circunstancias accidentales excluye la ocurrencia de responsabilidad por daños.

Palabras clave: fuerza mayor; contexto del caso; fuerzas de policía; responsabilidad civil; despido.

\section{Introduction}

The peculiarity of the work of the police is that they constantly have to apply preventive and coercive measures, and any mistakes in the application of these measures and the performance of official duties in general can lead to physical and moral suffering of a person whose rights and freedoms have been violated because of wrongful acts. Civil liability of police officers in this case is a means of deterring illegal behavior, as it entails the application of property sanctions that lead to the deterioration of the financial situation of the perpetrators. 
Civil liability is an effective means of deterring police officers from illegal behavior, as proven by many studies of both domestic and foreign scientists. If disciplinary liability is a form of internal control, as official investigations of police misconduct are conducted by disciplinary commissions composed of the employees of the same police department where the offender is serving, then civil liability is a form of external control because anyone whose rights or interests are violated as a result of illegal actions of police officers, have the right to file a lawsuit and demand the perpetrators be brought to justice.

The principle of "responsibility for guilt" is enshrined in civil law, which means that civil liability is not absolute, i.e. it extends to certain limits. These limits are the circumstances that lead to the release of a person from the obligation to bear adverse property consequences. The offender is released from civil liability in the absence of one or more conditions for accountability. The grounds for release from liability may be provided by law or contract.

The general grounds for exemption from liability for breach of obligation are listed in Art. 617 of the Civil Code of Ukraine (Law of Ukraine, 2003). One of the unconditional grounds for exemption from liability for breach of obligations in civil law is force majeure.

The category of force majeure belongs to the most general legal concepts, which are used not only by specialists in civil, but also in criminal, administrative, labor and other branches of law. It owes its origin to the law of ancient Rome. The expression "vis major" is found in the sources of Roman law in relation to sales, loan and other contract. For example, the owners of steamers, hotels and inns were responsible for the loss and damage of the accepted property, even in the absence of their own fault, but were released from liability if the damage was caused by force majeure. Force majeure (vis maior) was defined by the Romans as the objective factor that did not depend on the will of the person concerned. Thus, the destruction of a thing as a result of natural (flood, earthquake) or social catastrophe, fire, robbery was considered accidental.

The category of force majeure passed from Roman law to the legislation of other countries, including Ukraine.

\section{Research methods}

The research methodology is based on using both general scientific (dialectical, formal and logical, system and structural, etc.) and special methods (historical, comparative and legal, etc.), which were used to clarify the nature and features of force majeure in civil legislation of Ukraine. 
Strelbytska Lilia, Strelbytskyi Mykola, Shemchuk Viktor, Rizak Mykhailo y Kulhavets Khrystyna 374

Features of civil liability of police officers for damage caused under the influence of force majeure

The use of the dialectical method allowed to analyze various doctrinal concepts of recognizing certain life circumstances as force majeure, to consider the issue of force majeure in inseparable unity with other related legal phenomena.

Formal and logical method was used in defining such basic concepts of this study as force majeure, case (event), significant change of circumstances.

Force majeure was investigated as an element of the system of grounds for exemption from civil liability using the method of system and structural analysis.

Historical method allowed us to trace the evolution of the legal regulation of force majeure under Roman private law, civil law of Soviet and modern periods.

Comparative and legal method was used in the process of comparative analysis of signs of force majeure and their variants under the legislation of Ukraine, as well as in the analyses of force majeure subjective and objective theories.

\section{Literature Review}

The issues related to force major have been a study topic for number of researches all over the world. For example, Brunner (2009) studied force majeure in international commercial arbitration as an excuse under general contract principles. He considered this circumstance as the grounds for exemption from liability for non-performance of the agreement along with hardship and frustration.

Augenblick and Rousseau (2012), having considered the problem of force majeure, state that there is no unique approach to its definition; each country puts forward its own requirements to invoke its presence. They also examined the relevant court practice, which allowed them to determine three main principles of force majeure: its foreseeability; the impossibility to avoid or overcome the impediment or its consequences; failure to give timely notice.

Kokorin and Van der Weide (2015) carried out a comparative analysis of the approaches adopted in response to situations of force majeure (trade embargoes) and unforeseen change of circumstances (currency fluctuations) by such States as Russia, Germany and France. To archive this goal they studied the history of each country, as well cultural aspects and the features of law and economy, which led to the establishment of the respective approaches. 
In the course of the study we also used the scientific findings of the following Ukrainian and Russian scientists: Kryzhanovskaia (2010), Lebedev and Nytsevych (2007), Niemtseva (2014), Pavlodskyi (1972), Reznichenko and Tserkovna (2009), Sirokha et al (2020) and many others.

\section{Results and Discussions}

The Civil Code of Ukraine does not provide the concept of force majeure; the legislator only names it as a ground for release from liability for breach of obligation. Thus, according to Art. 617 of the Civil Code of Ukraine, "a person who violated the obligation is released from liability for breach of obligation, unless he (she) proves that the violation occurred as a result of an accident or force majeure". It is up to the person who breached the obligation to prove the existence of an accident or force majeure. It is he (she) who must provide the relevant evidence in case of dispute.

There are two main theories of force majeure: objective and subjective ones. According to the subjective theory, force majeure is an event that could not be prevented by the person who caused the damage, despite a high degree of diligence, care and foresight. Thus, the presence of force majeure is directly associated with subjective qualities - care and diligence (caution), i.e. based on the assessment of the capabilities of the perpetrator (Kryzhanovskaia, 2010).

In our opinion, the understanding of force majeure by the supporters of subjective theory is incorrect, because it does not contain clear and definite criteria for the differences between case (event) (which is provided by Art. 617 of the Civil Code of Ukraine) and force majeure.

The supporters of the objective theory, on the other hand, try to identify the signs of force majeure in the phenomena themselves and their properties that exceed human capabilities. They distinguish between a simple case (event) and a qualified case (force majeure), depending on whether it belongs to normal risks of a particular activity or arises beyond the activity. According to their opinion, force majeure is such a case (event), which does not belong to the normal risks of activity. Objective theory lists two main features of force majeure:

1) this phenomenon is external to the activity, in which area the damage was caused;

2) this phenomenon is extraordinary in the force of action, spontaneous, which can not be resisted by human forces (Kryzhanovskaia, 2010).

Henkin (1949) distinguishes between the concepts of chance and force 
Strelbytska Lilia, Strelbytskyi Mykola, Shemchuk Viktor, Rizak Mykhailo y Kulhavets Khrystyna 376

Features of civil liability of police officers for damage caused under the influence of force majeure

majeure through causal relationship. He writes that guilt and incident are among the necessary causality, and force majeure is associated with the concept of accidental causality.

Matvieiev (1963) in particular, noted that the case (event) and force majeure in terms of their causal conditionality are in different spaces; the case (event) as a concept opposite to guilt is in the space of objectively necessary connections between the acts (omission) of the perpetrator and harmful result; force majeure, as a concept not related to the subjective element of guilt, on the contrary, is in the space of random links between the sphere of activity of the perpetrator and the damage caused.

However, the definition of force majeure proposed by the supporters of objective theory is also not unconditional. This theory cannot fully explain the concept of force majeure, as it excludes a causal link between the offender's activities and the damage caused. Based on the idea of objective theory, the damage is caused by external emergency factors that the offender could not have foreseen. But this statement is not true, because the damage is caused by the action of the offender, and external emergencies cause it.

And therefore, it is necessary to support the position of Bieliakova (1967), who proposed two points that must be taken into account when clarifying the concept of force majeure, namely: external one - for the subject (extraordinary circumstances - floods, lightning, hostilities, etc.) and internal one - damage caused not by the actions of this extraordinary external event directly, and the activities of the offender (causation is required) came under the influence of this external emergency, and therefore caused damage. For example, the brakes of the police car went down during patrolling. The car, having lost control, crashed into another car, which caused material damage to its owner. In this case, the damage is in the necessary causal link with the activities of the source of increased danger, which was lost control by the police officer.

Most scientists share the view that force majeure is nothing more than a qualified case (event). However, it is necessary to distinguish between these two concepts, because in case of force majeure the obligated person is exempt from civil liability both in the presence of guilt and in its absence, and in case of the event the obligated person is responsible only for the presence of guilt. The science of civil law knows two ways to solve the problem of distinguishing force majeure and case (event). One of them is that it is proposed to distinguish between case (event) and force majeure on the basis of causation. Another one lies in the fact that it is possible to distinguish force majeure from the case (event) by considering force majeure as a circumstance endowed with certain specific features. It is this point of view is reflected in all legal definitions of force majeure (Pavlodskyi, 1972). 
Prymak (2008) believes that the case (event) as a subjective phenomenon characterizes the behavior of the obligated person, is objectively manageable and arises only because of the limitation of intellectual and strongwilled abilities of the subject, resulting from specific situation. Instead, the objective case (force majeure), in contrast to the simple case (event), appears as a result of external influence and occurs inevitably regardless of any efforts that could actually be made to eliminate this influence.

According to Niemtseva (2014), the main difference between force majeure and case (event) is as follows: 1) force majeure is an objectively inevitable event under certain conditions not only for the person who caused the damage, but also for other persons at the achieved level of development of science and technology, and the case (event) is objectively the opposite, but it cannot be prevented by a certain person; 2) force majeure is an extraordinary event that cannot be foreseen by the person who caused the damage, the person is given the opportunity to predict the amount of damage under the case (event); 3) force majeure is always an external event in relation to the activities of the person who caused the damage, and the case (event) is, as a rule, an internal circumstance in relation to his (her) activities.

In our opinion, if we compare force majeure and case (event), we can identify the following differences: 1) force majeure is a coincidence that only complements the necessity inherent in the activities of the offender. The case (event) acts as a coincidence, which is a form of expression of the need inherent in the activities of the obligated person; 2) force majeure is always an external event in relation to the sphere of activity of the obligated person. The case (event) is usually an internal circumstance in relation to an activity that causes harm; 3) the extraordinary nature of force majeure does not depend on its predictability. The case (event), in turn, is an extraordinary phenomenon precisely because of its unpredictability; 4) the consequences of force majeure are inevitable not only for the offender, but also for other persons engaged in the same type of activity and under the same conditions. The inevitability of the case is determined based on the abilities of a particular person.

Thus, force majeure is an unconditional basis for exemption from civil liability. The Civil Code of Ukraine defines force majeure as an extraordinary or inevitable event under certain conditions (Paragraph 1, Part 1, Article 263 of the Civil Code of Ukraine). In practice, natural phenomena (earthquakes, storms, snowdrifts, landslides, floods, etc.) as well as some social phenomena (epidemics, hostilities, severance of diplomatic ties, strikes, orders of the competent authorities prohibiting the implementation of actions under the obligation) are considered as force majeure.

Ovsieiko (2009) believes that there are three types of force majeure: 1) force majeure of physical nature - earthquakes, fires, catastrophes, 
Strelbytska Lilia, Strelbytskyi Mykola, Shemchuk Viktor, Rizak Mykhailo y Kulhavets Khrystyna 378

Features of civil liability of police officers for damage caused under the influence of force majeure

epidemics (epizootics), hurricanes, eruptions, floods, tsunamis, droughts, frosts, crop failures, other natural and man-made cataclysms (natural phenomena or natural disasters). One should keep in mind that the concepts of force majeure, natural phenomena, or natural disasters are not identical. First of all, it should be noted that there are differences between force majeure and natural disaster: force majeure in some cases includes the phenomena of social events, in particular, caused by hostilities; natural disaster is not always can be considered as force majeure, for example, if the damage caused by a natural disaster could have been prevented by the defendant.

Further, it is impossible to equate the concept of natural phenomenon and natural disaster. Thus, natural phenomenon reflects only the manifestation of known forces of nature without indicating destructive consequences and without specifying their intensity, and in terms of natural disaster is already the action of natural forces. Besides, the difference between these concepts is that we speak of a natural disaster in the case when there is a phenomenon grandiose in its harmful effects. Natural phenomena do not have such a sign, because the grandiose nature of harmful effects is out of question when causing damage by a source of increased danger, for example, in the event of a lightning strike. In this case, there is no sign of grandeur. Thus, natural phenomena and natural disasters are a measure of the realization of force majeure.

2) force majeure of social nature - wars, revolutions, uprisings, coups, terrorist attacks, etc. Legal literature includes outbreaks of epidemics, epizootics; spills of dams, which took place as a result of insufficient validity of calculations of water pressure and strength of building structures, to the phenomena of a social nature. In addition to the above, the severance of diplomatic and trade relations also has signs, in some cases, of force majeure.

3) force majeure of legal nature - the issuance of various prohibitions, restrictions, embargoes, moratoriums, etc. by the competent authorities.

Kharytonov (2007), in turn, notes that the properties of force majeure are: 1) extraordinary (it goes beyond ordinary everyday phenomena); 2) inevitability (it cannot be prevented and overcome at the current level of development of science and technology).

The term "extraordinary" means "exceptional; superior; extra-large"; "the one that exceeds the usual measure; not as exceptional as ever" (according to the explanatory dictionary of Russian language). In the academic explanatory dictionary of the Ukrainian language, this term is interpreted as "very strong in its degree of expression and not similar to others; exceptional". 
At the same time, the extraordinary force majeure is expressed not so much in power as in the atypicality of a phenomenon. Indeed, in judicial practice, adverse weather conditions are a simple case (event). But if, for example, there are freezing temperatures in April or May, which is uncommon phenomenon for this time of year, and it caused damage to the agricultural activities not only of the obligated person, but also the activities of other people working in the same field, then it is force majeure.

Niemtseva (2014) agrees with this statement, arguing that extraordinary is not an ordinary, common circumstance that can cause some difficulties for the parties, although it does not go beyond the ordinary (melting snow in the mountains, annual seasonal monsoon rains, etc.), but and an extraordinary event that is not ordinary.

The second property of force majeure is inevitability. This feature is more difficult to investigate, because the inevitability is specific (under certain conditions). Inevitability must be interpreted in relation to the abilities of a particular debtor, not the abilities of society as a whole. Inevitability cannot occur in the case of offenses on the part of the debtor, its employees, contractors, uncertainty or lack of solvency of the debtor, market failures. The actions of public authorities and local governments are generally considered inevitable. Illegal actions of the authorities are not considered force majeure. Legitimate coercive actions of the authorities aimed at imposing sanctions on the debtor for the offense are not considered inevitable (Lebedev and Nytsevych, 2007).

In order for force majeure to become the basis for releasing the offender from liability, the person who violated the obligation must prove: 1) the existence of force majeure; 2) its extraordinary nature; 3) the inability to prevent damage under the given conditions; 4) the causal link between these circumstances and the damage caused. Therefore, it is necessary not only to confirm the existence of force majeure, but also the fact that it prevented the fulfillment of the obligation.

However, it is sometimes difficult, and sometimes impossible, to assess whether a circumstance will be recognized as force majeure in advance. For such an analysis, two main criteria should be used: the ability of a person to anticipate the relevant circumstances and the ability to prevent adverse consequences under certain circumstances. A negative answer to at least one of the above questions is enough to conclude that the offender is not held accountable (Lebedev and Nytsevych, 2007).

That is, in order to release the perpetrator from liability, it is necessary to prove that force majeure deprived the perpetrator of the opportunity to prevent damage. Force majeure belongs to the category of relative concepts, because what is inevitable at one level of development of science and technology is completely avoidable under other conditions. Therefore, 
Strelbytska Lilia, Strelbytskyi Mykola, Shemchuk Viktor, Rizak Mykhailo y Kulhavets Khrystyna 380

Features of civil liability of police officers for damage caused under the influence of force majeure

the court, determining the possibility of classifying the phenomenon as force majeure, clarifies all the specific circumstances of the damage in this case, in particular, place, time, etc. As a general rule, force majeure releases the debtor from liability in all cases; however, the content of Part C of Art. 1166 of the Civil Code stipulates that damage caused by injury, other damage to health or death of an individual due to force majeure is subject to compensation in cases prescribed by law.

Since neither Art. 1176 of the Civil Code of Ukraine (1995), nor the Law "On the procedure for compensation for damage caused to a citizen by illegal actions of bodies conducting investigative activities, pre-trial investigation, prosecutor's office and court" (which is a specific legal act that enshrines the procedure for compensation of damage caused by police officers) does not enshrine that law enforcement officers are liable in case of force majeure forces, we can conclude that the police are released from liability if they can prove the fact of its influence.

\section{Conclusion}

Based on the provisions of the civil doctrine and the basic approaches to the understanding of the concept of force majeure, the legislator enshrines them in a number of key provisions of the Civil Code of Ukraine. Thus, as a general rule, the person who caused the damage is released from its compensation if he (she) proves that the damage was not his (her) fault, and therefore he is not obliged to such compensation in case of accidental damage. On the other hand, Chapter 82 of the Civil Code of Ukraine further contains numerous exceptions from this general rule and cases of imposing the obligation to compensate for the damage caused on a person, regardless of his (her) guilt. In particular, we are talking about innocent liability for damage caused by a source of increased danger (Articles 1187-1188 of the Civil Code of Ukraine) and damage caused by public authorities, local governments, their officials in different areas (Articles 1173-1176 of the Civil Code of Ukraine). The only grounds for exemption from the obligation to compensate for such damage, based on the legislative provisions of Part 5 of Art. 1187 of the Civil Code of Ukraine and the above scientific positions, there is only force majeure and intent of the victim. Based on the doctrinal provisions and the conclusions obtained in the context of the conditions of tort obligations (illegality, liability without guilt and the peculiarities of causation in the obligations to compensate for damage caused by force majeure), we consider it necessary to extend these (and only these) grounds for excluding civil liability of police officers.

However, some researchers believe that force majeure can only be the limit of innocent responsibility. If the completed tort entails liability 
on the basis of guilt, then the influence of force majeure on the conduct of the delinquent only indicates the absence of guilt of the latter (i. e. the conditions of his (her) liability). In other words, force majeure loses the significance of the circumstance that release from liability when imposing it on the basis of guilt (Reznichenko and Tserkovana, 2009).

However, the case law on the exemption of police officers from civil law due to force majeure is quite limited to formulate specific conclusions. Therefore, we proceed from the general rule that the recognition of the fact that the damage is the result of force majeure in tort law precludes the occurrence of obligations to compensate for the damage caused.

\section{Bibliographic References}

AUGENBLICK, Mark; ROUSSEAU, Alison. 2012. "Force Majeure in Tumultuous Times: Impracticability as the New Impossibility" In: The Journal of World Investment \& Trade. Vol. 13, No. 1, pp. 59-75.

BIELIAKOVA, Anna. 1967. Compensation for damage caused by a source of increased danger (Liability of owners of a source of increased danger). Publishing House of Moskow University. Moscow, Russia.

BRUNNER, Christoph. 2009. Force Majeure and Hardship Under General Contract Principles. Kluwer Law International. Netherlands.

HENKIN, Dmytryi. 1949. "Review of meetings of the civil law sector" In: Soviet State and Law. Vol. 5, No. 11, pp. 69-73.

KHARYTONOV, Yevhenii; STARTSEV, Oleksandr. 2007. Civil law of Ukraine: textbook. Istina. Kyiv, Ukraine.

KOKORIN, Ilya; VAN DER WEIDE, Jeroen. 2015. "Force Majeure and Unforeseen Change of Circumstances. The Case of Embargoes and Currency Fluctuations (Russian, German and French Approaches)" In Russian Law Journal. Vol. 3, No. 3, pp. 46-82.

KRYZHANOVSKAIA, Alla. 2010. Civil liability for damage caused in connection with the use of complex software products: scientific practice. CONTRACT; Walters Clover. Moscow, Russia.

LAW OF UKRAINE. 1995. On the procedure for compensation for damage caused to a citizen by illegal actions of bodies conducting investigative activities, pre-trial investigation, prosecutor's office and court of December 01, 1994 no. 266/94-VR. Available online. In: https://zakon. 
Strelbytska Lilia, Strelbytskyi Mykola, Shemchuk Viktor, Rizak Mykhailo y Kulhavets Khrystyna

rada.gov.ua/laws/show/266/94-\%Do\%B2\%D1\%80\#Text. Date of consultation: 17/04/2020.

LAW OF UKRAINE. 2003. Civil Code of January 16, 2003 no. 435-IV. Available online. In: https://zakon.rada.gov.ua/laws/show/435-15. Date of consultation: 17/04/2020.

LEBEDEV, Vladymyr; NYTSEVYCH, Artur. 2007. "Irresistible force" In: Legal practice. No. 43, p. 513. Available online. In: http://pravo.ua/ article.php?id=10008052. Date of consultation: 17/04/2020.

MATVIEIEV, Hennadyi. 1963. "On the concept of force majeure in Soviet civil law" In: Soviet State and Law, Vol. 3, No. 8, pp. 90-98.

NIEMTSEVA, Alina. 2014. "The grounds for release from innocent liability in civil law" In: Bulletin of the Ministry of Justice of Ukraine. Vol 1, Num. 1, pp. $78-85$.

OVSIEIKO, Serhei. 2009. "Force majeure: the concept and reservations" In: Exchange Control and Foreign Trade Activities. Vol. 5, No. 5, pp. 62-79.

PAVLODSKYI, Efym. 1972. Case and force majeure in Soviet civil law. PhD. AllUnion Research Institute of Soviet legislation.

PRYMAK, Volodymyr. 2008. "The signs of force majeure in civil liability" In: Legal Ukraine. Vol. 9, No. 6, pp. $60-67$.

REZNICHENKO, Semen; TSERKOVNA, Olena. 2009. The grounds for exemption from civil liability for damages: theory and practice: a monograph. ODUVS. Odesa, Ukraine.

SIROKHA, Dmytro; FELYK, Vasyl; PODOROZHNII, Yevhen; PODOROZHNII, Artek. 2020. "Basic aspects of the compliance with discipline and legitimacy within the official activities of police" In: Amazonia Investiga. Vol. 9, No. 25, pp. 487-492. Available online. In: https://www. amazoniainvestiga.info/index.php/amazonia/article/view/1098. Date of consultation: 17/04/2020. 


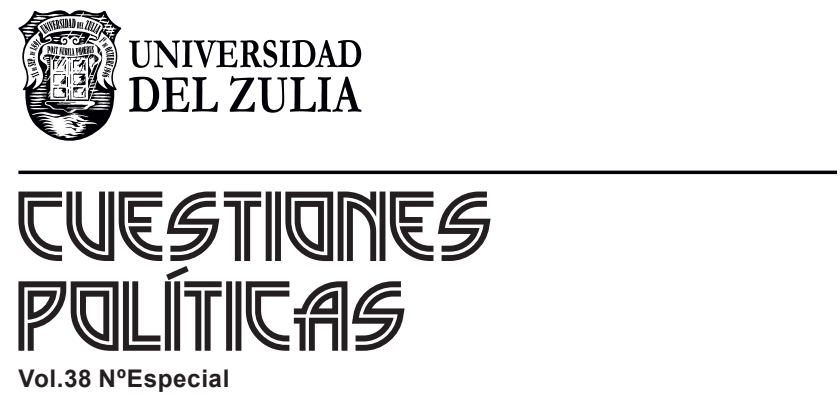

www.luz.edu.ve 